\title{
Personal Narrative: Bloody Precarious Activism in Uganda
}

\author{
Stella Nyanzi
}

Editor's Note: I am honored and humbled to include Stella Nyanzi's essay in our Handbook. When we refer to menstruation as structural, we often mean that menstruation is political. Menstruation exemplifies how women's and menstruators' bodies and sexualities are politicized. No one can speak better to that than Stella Nyanzi whose research and activism bridges gender, sexuality, marginalized communities, LGBTIQ rights, and freedom of expression. In her essay, she describes and analyzes her dissident activism against the president's unfulfilled promise of providing sanitary pads to schoolgirls in resource-poor communities in Uganda through the \#Pads4GirlsUg campaign.

Stella Nyanzi began drafting this essay after being released from prison on bail in May 2017, which she describes below. She had been arrested for her criticism of Janet Museveni in her role as Minister of Education and the President, Yoweri Museveni, related to his unkept promise to provide menstrual pads to girls. In November 2018, she was arrested again and was accused of "cyber harassment and offensive communication," again related to a critical poem she wrote about the Ugandan President, in which she employs a graphic description of his mother's vagina. Amnesty International and PEN International have called for the charges against her to be dropped - thus far to no avail. Stella Nyanzi, a mother of two twin boys and a girl, turned down the option of posting bail explaining that it would be just an illusion of freedom. We jointly finalized her essay with the support of Adrian Jjuuko who discussed the revised version with her when visiting her in prison as she is denied any reading materials. At the time this Handbook goes to print, Stella Nyanzi is still imprisoned. Yet, her powerful words permeate the prison walls-Inga Winkler. 


\section{Introduction: Severely Punished for Menstrual Activism}

On April 7, 2017, I presented a pitch about the urgent need for sustainable menstrual health and hygiene to a widely publicized Rotary Club Fellowship in Kampala City. On my way home, ten unidentified armed individuals abducted me from a vehicle. They drove around the dark city for three hours, and then dumped me in a cell at Kira Division Police Station. My captors neither had an arrest warrant, nor informed me of the charges. However, on the long circuitous drive around the city, they repeatedly condemned my acerbic criticisms of the ruling party in Uganda for various failed promises. Specifically, they ridiculed me for publicly challenging the president and his wife for reneging on a promise to provide free sanitary pads to schoolgirls. On the third day of my detention with neither charge nor trial, I finally learnt that I was charged with using social media for public solicitation of money and fundraising for sanitary pads which I distributed across the country.

I was not surprised by these attempts to criminalize my social media activity. The month before my arrest, I had already been subjected to grueling interrogation at the headquarters of the Criminal Intelligence and Investigation Department (CIID). I had also been indefinitely suspended from my permanent employment at Makerere University—allegedly because I insulted the First Lady who was also the Minister of Education. My home was under intense surveillance. My family's movements were monitored and our family vehicle was trailed. My phone communication was tapped. I was barred from boarding a plane to attend an academic conference at the University of Amsterdam and indefinitely banned from traveling abroad. And I received several anonymous death threats via social media, phone, and radio.

After spending three nights in detention, I was arraigned before the Chief Magistrate's Court amidst heightened security and charged with cyber harassment and offensive communication against the president of Uganda. Before I was able to enter a plea, the state prosecutor submitted an application to the court to subject me to involuntary mental examination and treatment before proceeding with the hearing. After I plead not guilty of the charges, the Chief Magistrate refused my application for bail. Instead, he remanded me to Luzira Women's Prison, a maximum-security prison, where I spent 33 days and nights.

\section{The President's Broken Promise}

At the height of his presidential campaign in November 2015, incumbent President Yoweri Museveni promised that if he was re-elected into power, he would provide free text books, pens, computers, and sanitary pads to students attending Universal Primary Education in Uganda. He pointed out that access to pads would be crucial for girls to stay in school. At a campaign rally in November 2015, he explained 
I want all our daughters to attend school and remain there until they complete their studies. One of the reasons that force our daughters out of school is that when their periods start, they do not have sanitary pads. When they are in class, they soil their dresses. So they run away from school. ${ }^{1}$

However, after being sworn in as president of Uganda, Museveni reneged on his promise of free pads. His wife, Janet Museveni, who was appointed Minister of Education, announced that the Ministry of Education had no money in the 2016-2017 financial year to fulfill the president's promise of free sanitary pads for schoolgirls.

As a Ugandan citizen, a woman who is still menstruating, and a member of the opposition voce populi, I intensified my criticism of the regime's failed promises-specifically focusing on the cruel exploitation of schoolgirls' lack of menstrual products. I was horrified by the blatant manipulation of poor girls' menstruation in order to enhance election votes, only to discard the promise after being sworn in office as president. I posted many critical pieces denouncing Janet Museveni's position as 'Mama of the nation,' questioning her intellectual ability to formulate relevant education policies, and challenging Yoweri Museveni's unending list of failed promises. Characteristically deploying sexual metaphors and allegorical comparisons between genitalia and other body parts, my posts were aimed at provoking thought, discussion, debate, and action. The posts went viral.

\section{\#Pads4GirlsUg: Popularizing Menstrual Hygiene EduCATION ANd Materials}

After being summoned to the headquarters of the CIID for interrogation, I decided subvert this interrogation into a protest by inviting interested individuals to bring sanitary pads to the CIID offices. I posted a photo on Facebook of the summons letter alongside an appeal for contributions of sanitary pads that I would deliver to schoolgirls. The Facebook post was widely shared and attracted the interest of local journalists, activists, and politicians. Notably, Hon. Betty Bakireke Nambooze, a prominent female Member of Parliament from the opposition party came to the CIID headquarters and gave several interviews condemning President Museveni's failure to fulfill his campaign promise to provide free sanitary pads to schoolgirls and spoke in favor of my criticism of the regime's failures and misgovernance. To those who opposed my language of protest because they claimed it was vulgar, obscene, profane, disrespectful, and thus culturally unacceptable, Hon. Betty Bakireke Nambooze explained why I was particularly authorized to speak in this way. First, my studies focused on sexualities, and second, among the Baganda there is customary license for a Nalongo like myself-the mother of twins - to express herself graphically. She stated,

I have come to see Stella. Where are the Women Members of Parliament who represent women in the districts? They should be here in solidarity with Stella 
because she is doing their work . . . People should understand Stella. She is not vulgar just for the sake of being vulgar. This is what she studied. And in the struggle to liberate oneself, one uses what one has. Those are the tools she has. People who think that she speaks vulgar words should also speak their own words because this is an opportunity that they have to raise their decent words besides Stella's words that they say are indecent so that the world chooses their own as the correct ones . . . Also people should know that Stella is a Nalongo as a mother of twins. I learnt that in Buganda the mothers of twins have special permission to use whatever language to express their grievances ...2

After my five-hour long interrogation, I exited from the offices of the CIID Director and made a televised appeal to individuals to continue donating menstrual hygiene materials. This, in effect, was the public launch of the \#Pads4GirlsUg - a citizen-led campaign to collect and distribute pads to schoolgirls in Uganda and to provide menstrual education as a direct challenge to President Museveni's failed promise.

When I first requested citizens to donate pads and funding for \#Pads4GirlsUg, I was overwhelmed by the donations that began coming in. People giving money ranged from notable politicians to ordinary Ugandans struggling to make ends meet. For example, Hon. Muhammad Nsereko, a Member of Parliament for Kampala District, enthusiastically encouraged us and gave us 1 million Ugandan Shillings. An elderly farmer sold her chicken and contributed 15,000 Shilling. Random bodaboda men (motorcycle taxi drivers) donated as little as 3000 Uganda Shillings-which was sufficient to procure a packet of twelve disposable sanitary pads. The unplanned but extensive publicity through both public media and social media spread the word about the \#Pads4GirlsUg campaign, not only in Uganda but around the world. Through these donations, we were able to provide menstrual hygiene materials to almost 3000 schoolgirls, young mothers, and teachers in five districts of Uganda.

Although menstruation is a natural biological process that most adolescent girls undergo, it is widely shrouded in secrecy and shamed in Uganda. When students shared their personal experiences with the \#Pads4GirlsUg team, many revealed that they began their menstrual period without having received any relevant education or talks. Given this widespread lack of relevant information, it was important for us to include menstrual health education in the package that we delivered to schools and communities. We gave talks to both male and female students and available staff about menstruation, menstrual health, and hygiene. We distributed age-appropriate booklets to students. Alongside the teaching, we demonstrated how to use, clean, store, and dispose of both the re-useable and disposable sanitary pads. We foregrounded questions and queries of clarification from the students. In each of the school and community meetings, we collected questions and individually addressed these drawing from our expertise, experience, and research. To shatter the stigma and dismantle the secrecy around menstruation, I also 
introduced the students to a cheerful easy chant, to which we all danced and publicly enacted the motions of wearing menstrual hygiene materials.

\section{Backlash Against the \#Pads4GirlsUg Campaign: Undermining and CRIMINALIZING}

Our opponents greatly criticized the \#Pads4GirlsUg campaign, specifically condemning my insistence on offering menstrual education to both girls and boys because leaving out the boys entrenched their ignorance about the normality of menstruation. In a rare television interview, First Lady and Minister of Education, Janet Museveni, criticized me for publicly teaching girls and boys about menstruation.

And I thought that we cannot have a teacher really do that. And as an example to children she is teaching. And even go in front of a classroom and try to demonstrate wearing a sanitary pad . . . in front of a classroom. I didn't understand what character that is. So I wanted to tell people of good will who really were hearing that and reading it from I think social media that I forgive her. And I let the people of Uganda judge. ${ }^{3}$

As such, Janet Museveni, shamed me for being 'an educationist' who was publicly using offensive language to criticize the government's failure to fulfill the president's campaign promise. Instead of apologizing to Ugandans because her husband reneged on his promise and appropriated rural poverty to garner more votes by manipulating voters, and instead of addressing the critical issues at hand, she audaciously declared that she was forgiving me for insulting her.

Similarly, Rosemary Nansubuga Seninde, a Member of Parliament and Minister of State for Primary Education in Uganda also critiqued the public discussion of menstruation because it broke taboo and secrecy. In a public address on April 7, 2017 she said,

For a girl-child to tell people that 'I'm menstruating,' it was a taboo. You would not tell anyone that your period is now. That you are in the period, because it was regarded as something secret. It was only supposed to be known by the mother only. Not anyone else. Not even your sisters. Not even your brothers. Only your mother. You would whisper to the mother. Then she would help you, teach you how to do it, how to clean yourself, how to wash your pants, how to prepare your pad and so on and so forth. And you would go to school. Nobody would even know you are in your period. Are our girls here? Can you stand up our dear girls? Come and learn the culture of Buganda . . . . Nobody is interested in knowing that you are in your period. Who is interested? But what is so shocking and what is so surprising is that Ugandans are waiting for President Museveni to buy pads for Uganda children . . . 
These attempts to shame and denigrate our provision of menstrual education to students generated debates within Uganda. Rather than align themselves with sensitization and public education about menstrual issues, it was disheartening that many powerful public officials adopted moralizing tones steeped deep in cultural shaming, taboo, and secrecy. Many public officials criticized our education methods and processes-claiming (correctly) that we were breaking social norms and abusing cultural taboos which they claim forbid the discussion of menstruation outside the intimate circles of paternal aunts and their nieces.

The \#Pads4GirlsUg was heavily politicized in Uganda to the point of criminalization. As the person at the forefront of the campaign, I was maligned as an obscene, vulgar, profane, rude, radical, and angry woman who was dangerous to the status quo and a source of pollution for respectable people. My language of protest on Facebook, Twitter, and public media was criticized for being overly graphic and appropriating sexual imagery. My previous political participation in demonstrations and LGBTIQ pride parades were alluded to as proof of my lewdness, immorality, and vulgarity. Therefore, different public officials, religious clerics, traditional leaders, and even some women leaders publicly condemned the fact that I was at the forefront of the \#Pads4GirlsUg campaign. Conservative individuals from my ethnic group, clan, religious denomination, and professional affiliations categorically disassociated themselves from me because they argued that a foul-mouthed woman was a-cultural, un-African, ungodly, immoral, unprofessional, and irreverent.

Given that most of the members of the \#Pads4GirlsUg Working Group were publicly known as local LGBTIQ rights activists, those who wanted to discourage support for our activities strategically capitalized on associating our project with a 'homosexualizing mission.' I was portrayed as a fervent supporter of homosexuality who was collaborating with local LGBTIQ rights activists to recruit schoolgirls into homosexual behavior. These claims were so preposterous that some homophobic opponents went as far as claiming that our \#Pads4GirlsUg campaign was providing 'homosexual pads' that would convert the recipients into lesbians. These accusations of recruitment of minors into homosexuality were further enhanced with assertions that I was taking lesbians into secondary schools under the pretext of distributing free sanitary pads.

Opposition to our campaign increased by seeking to influence radio and television stations, the schools meant to benefit from the campaign, as well as the pad suppliers. Radio and television stations that were previously receptive and supportive of our activities changed their open policies toward us. As the campaign grew in popularity among disgruntled citizens, public officials' narrative about \#Pads4GirlsUg became more negative, and public media houses were less willing to engage with us. With time, it became clear that these public media houses were under instructions not to host any members of the \#Pads4GirlsUg Working Group. 
While some schools were initially scheduled to receive \#Pads4GirlsUg products, they later withdrew their willingness to host us. Even in private schools, there was real pressure to comply with the orders from the Ministry of Education which ultimately had the power to withdraw licenses of operation and exclude the school from direct benefits of the government. After negotiations in some districts and schools, we agreed that it would be foolhardy to deny the students the menstrual materials but it would also be reckless to force the school to disobey the instructions. Instead we drove our loaded vehicle outside the school grounds and set up our \#Pads4GirlsUg paraphernalia just outside the school gate. All female students and staff members who were interested in participating in the campaign, met us outside the school premises and received a comprehensive package with educational information and materials.

As part of the backlash, the Minister of Education also raised doubts against the distribution processes, distributors' credibility and intentions, and the quality of distributed sanitary pads. Given that the campaign necessarily confronted and challenged the most powerful individuals in Uganda, our sanitary pad suppliers who were initially willing business partners subsequently became fearful to be associated with us. Although inevitable, it was shocking when a key supplier of the cheapest disposable sanitary pads used in the campaign turned down our cash payments for a bulk purchase. It became apparent that suppliers who provided us with menstrual products faced a real or imagined fear of surveillance by state agents, targeting for political witch-hunting, cancelation of trading licenses, imposition of unfair exorbitant taxes, and unnecessary product assessments.

Initially unbeknownst to us, police officers began trailing members of the \#Pads4GirlsUg Working Group who mostly appeared in media awareness programs. These police officers went as far as physically tracking us through our mobile phone numbers. As the surveillance intensified, police officers started following, surveilling, and hounding Working Group members. In my case, they went to my home in my absence and interrogated the house help, went to my children's school, trailed the personal vehicles of family members, and were listening into my conversations on my mobile phone. This culminated in several overt and covert threats of death, and the threat of torture of my children if I did not stop the \#Pads4GirlsUg campaign. Thus, as described above, it was not surprising when I was inundated with summons for interrogation and was detained without trial.

\section{Refusing to Be Silenced: Radical Rudeness}

Public officials sought to undermine our \#Pads4GirlsUg campaign by influencing schools meant to benefit from the campaign, radio and TV stations, and pad suppliers. The efforts they undertook to discredit our campaign demonstrate how deeply political—or rather politicized-decisions about pad distribution and menstrual health education are in Uganda. They painted a 
picture of me and other \#Pads4GirlsUg Working Group members as 'spreading' homosexuality, as un-African, and as vulgar and profane. Yet, I see radical rudeness as the only viable means to challenge those in power. As I have said elsewhere, challenging power isn't polite or beautiful. On June 16, 2019, my 45th birthday, I released 45 poems I have written in the Luzira Prison in Kampala where I am imprisoned once again since November 2018, including this one:

\section{Free Sanitary Pads}

In the twilight of the dictatorship

The dictator went really berserk.

He dipped the tight fingers of his iron fist

Into the menstrual blood of poor Ugandan girls.

In a frenzy of cheap popularity

He made another empty promise.

"Vote for me and I will give your daughters free sanitary pads to keep them in school!"

The dictator is a delinquent lying swine.

Gullible peasants with bleeding daughters

Switched their votes to the promise giver.

As they voted they remembered how

His tight fist was covered in fresh menses.

They recalled the belligerent sneer he wore

As he exposed the plight of their bleeding daughters.

"Vote for me and I will give your daughters free sanitary pads to keep them in school!"

The dictator is an exploitative thief of votes.

After swearing back into power

The dictator proved himself a liar.

He publicly washed the menstrual blood

Off his blood-stained thieving hands.

He delegated his drunk wife to lie about

The lack of funds for free sanitary pads.

Does he think we forgot his fake promise?

"Vote for me and I will give your daughters free sanitary pads to keep them in school!"

The dictator's biography is stained with menstrual blood. 


\section{Notes}

1. Excerpt of verbatim speech reprinted in Wesonga, N., and B. Oketch. 2015. “Museveni Promises Pupils Free Books, Pads." Daily Monitor, November 13, 2015.

2. Excerpt of translated interview. Interview telecast on television is available at: https://www.youtube.com/watch?v=W0P8_VH3wME.

3. Transcription of the television interview by the author.

4. Transcription of the public address by the author. For a newspaper report of her public address in Karamoja district, see Kolyangha, M. 2017. "Minister Blames Parents Over High School Dropout Rate in Karamoga." Daily Monitor, April 7, 2017.

Open Access This chapter is licensed under the terms of the Creative Commons Attribution 4.0 International License (http://creativecommons.org/licenses/ by/4.0/), which permits use, sharing, adaptation, distribution and reproduction in any medium or format, as long as you give appropriate credit to the original author(s) and the source, provide a link to the Creative Commons license and indicate if changes were made.

The images or other third party material in this chapter are included in the chapter's Creative Commons license, unless indicated otherwise in a credit line to the material. If material is not included in the chapter's Creative Commons license and your intended use is not permitted by statutory regulation or exceeds the permitted use, you will need to obtain permission directly from the copyright holder.

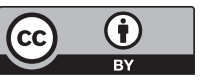

